\title{
Geotechnical investigations for locating an underground powerhouse in calcareous rocks, Himachal Pradesh, India
}

\author{
Imran Sayeed and Rahul Khanna \\ EG \& G Division, NHPC Ltd. \\ Faridabad, Haryana, India \\ sayeedimran2009@gmail.com
}

\begin{abstract}
The case pertains to a hydroelectric project (520MW) located in Kullu district of Himachal Pradesh. During the feasibility stage, surface powerhouse was proposed with an option of an underground alternative as well. In the detailed project report stage, when extensive investigations were undertaken for firming up the layout of the project, the underground location was further explored. However, weak carbonaceous shales were encountered due to which this underground alternative was not preferred. As the surface power house location was not attractive due to very deep open cutting as well as proximity to habitation, another alternative location about $2 \mathrm{~km}$ upstream was studied through a new $350 \mathrm{~m}$ long exploratory drift. Once again weak phyllite rock with thinly laminated slates was intercepted due to which second alternative location for underground powerhouse was not considered.The heterogeneity in geotechnical units which is so typical of Larji Group of rocks had posed a mammoth challenge in proposing a suitable site for locating underground powerhouse caverns viz., machine hall having dimension of $122.9 \times 23.2 \times 41.7 \mathrm{~m}$, transformer cavern having dimensions $96.45 \times 18 \times 25 \mathrm{~m}$ and a downstream surge chamber.
\end{abstract}

The study to locate a massive band of dolomite in order to accommodate the underground powerhouse complex and ensuring its continuity both ways has been very complicated and needed a thorough study of the geological conditions. Detailed geological mapping on 1:1000 scale was undertaken to locate a massive dolomite band of significant extent. Subsequently, another exploratory drift of $250 \mathrm{~m}$ length was excavated to confirm the extension of dolomite band along the longer axis of machine hall. Finally a suitable location was found. During investigation stage, about $880.5 \mathrm{~m}$ of exploratory drifting has been undertaken to study the three alternatives. Detailed 3-D geological logging on 1:50 scale of exploratory drifts has been done to evaluate the rock compositions, behavior, structural features such as joints, faults, shear/fracture zones etc. RMR rock classification system has been adopted to classify rock mass in terms of Good, Fair, Poor and Very Poor categories. Rock Mechanics and permeability tests were conducted to determine engineering properties of the rock mass. This paper describes a series of geotechnical investigations carried out at various alternatives to select most suitable location of power house complex within massive dolomite band. It also highlights the fact that detailed investigations and well considered decisions taken during the DPR stage help not only in timely completion of projects but also in keeping the project cost within estimates. This Power station has been commissioned in the year 2014.
Keywords-Powerhouse; geotechnical investigations; dolomitic limestone; geological mapping; exploratory drifting; drilling.

\section{INTRODUCTION}

Hydropower is one of the cleanest and cheapest forms of renewable energy. India is blessed with about 150,000 MW hydropower potential which is equivalent to $84,000 \mathrm{MW}$ at $60 \%$ load factor (CEA, 2015). Out of this, only about 25.4 percent of total potential has been tapped so far. Therefore, a large potential of this form of renewable energy is still untapped. Himalayas are the youngest mountain chains having undergone several phases of orogeny and are structurally deformed. The geology of this region is relatively complex and varying in nature. Development of any infrastructural project such as rail or road network, communication tunnels or hydro power plants in this region in a time bound and cost effective manner requires thorough understanding of geology of the area.

Hydropower projects big or small require several surface and underground structures such as dams, tunnels and large caverns whose designing and construction require thorough understanding of not only regional geology but geotechnical characterization as well. In some cases, the hostile geological conditions are unforeseen but it is also a fact that in a large number of projects, paucity of investigations, non-imperative decision making and improper contract management had lead to exaggeration of the problems. It is important to study such cases and device strategy for future development. However, it is more important to study those projects also which have been successfully developed in Himalayan region within stipulated time schedule in a cost effective manner. The systematic and detailed investigations during DPR stage and due consideration given to the existing geological conditions during designing stage itself has led to successful execution of such projects. The role played by various geological and geotechnical investigations in firming up the layout of such projects is a matter of study and appreciation. Correct site selection after detailed investigations is a important prelude for successful implementation of hydropower schemes.

One such project where selection of suitable location for an underground powerhouse was a critical issue is discussed. 
Delineation of a massive band of dolomite limestone within highly varying lithology of Lesser Himalayan region after detailed assessment of several other alternatives by means of various geotechnical investigations forms the theme of this paper.

\section{Geology of the Project AREA}

The Himalayas are abode of large glaciers, deep gorges and mighty rivers that hold a great potential for development of hydroelectric power projects. This paper present a case study from one hydropower project constructed on Sainj River which is a tributary of Beas. The projectcommissioned by NHPC Ltd. during 2014 is located in the Kullu district of Himachal Pradesh. It lies within the rocks of Lesser Himalayan zone of Kullu-Rampur belt belonging to Rampur and Larji Groups of Proterozoic age. The Banjar thrust passing near village Talara separates the two groups. It is nearly $3 \mathrm{~km}$ upstream of the powerhouse site. The other structural features of this area are Jutogh thrust and the Banjar-Rampur window enclosing within it the Larji window. Due to these structural features, the Larji Group which is youngest in age occupies the lower tectonic positions while the oldest Kullu (Jutogh) Group occupies a higher tectonic position. The regional tectonic features viz., Main Central Thrust (MCT) is about $35 \mathrm{~km}$ north and Main Boundary Thrust (MBT) is about $100 \mathrm{~km}$ south west of the project area.

TABLE I. LITHO-STRATIGRAPHIC SUCESSION OF LARJI GROUP

\begin{tabular}{|l|l|l|}
\hline \multicolumn{2}{|l|}{ North } & Naraul \\
\hline \multirow{4}{*}{$\begin{array}{l}\text { Larji } \\
\text { Group }\end{array}$} & Formation & $\begin{array}{l}\text { Quartz-arenite, grey phyllite \& diamictite. } \\
\text { White quartzite \& conglomerate with slate \& } \\
\text { phyllites. } \\
\text { Calcarenite, shale and slate. }\end{array}$ \\
\cline { 2 - 3 } & $\begin{array}{l}\text { Hurla } \\
\text { Formation }\end{array}$ & $\begin{array}{l}\text { Grey, white, pink and purple quartz-arenite } \\
\text { with shale partings. }\end{array}$ \\
\cline { 2 - 3 } & $\begin{array}{l}\text { Para conformity } \\
\text { Aut }\end{array}$ & $\begin{array}{l}\text { Grey dolomite with stromatolites. } \\
\text { Cream, grey \& purple limestone. } \\
\text { Grey dolomites. } \\
\text { Cream, \& purple limestone. } \\
\text { Grey dolomite with stromatolites. } \\
\text { Earthy calcareous conglomerates, gritty } \\
\text { dolomite with bands of pink and green } \\
\text { limestone. }\end{array}$ \\
\hline South & \multicolumn{2}{|l}{} \\
\hline
\end{tabular}

The Power house area lies within the rocks of the Larji Group which comprises of a sedimentary sequence of dolomite, limestones, quartzites and slates etc. This Groupoccurs as a tectonic window bounded by the Banjar thrust on all sides except in the west where it is concealed under the Jutogh thrust.

Structurally, the rocks of Larji Group have undergone large scale disturbance in the form of series of overturned folds and associated faults. These movements have resulted in shearing and crushing of the dolomite and quartzite member of Larji Group at several places. The lithostratigraphic succession of Larji Group and various rock units occurring in the area are shown in Table I. The above litho-stratigraphic succession shows that the larji group comprises of highly heterogeneous rock units and finding finding a massive strong and geotechnically sound band of Dolomite having sufficient thickness and persistence in order to locate suitably all major components of the sub surface Power house is very challenging task.

\section{PROJECT LAYOUT}

The Power house complex of the project comprises of a $20 \mathrm{~m}$ diameter circular shaped Surge shaft with height of $128.5 \mathrm{~m}$, two numbers circular shaped Pressure shafts having 4.5 diameter, a Machine hall having dimension of $122 \mathrm{~m}$ (length) $\times 22 \mathrm{~m}$ (width) $\times 41.7 \mathrm{~m}$ (height) along with a Transformer Cavern having dimension of $98.2 \mathrm{~m}$ (length) $\mathrm{x}$ $15.5 \mathrm{~m}$ (width) $\times 25.2 \mathrm{~m}$ (height) and 4 numbers downstream surge chambers having dimension of $15 \mathrm{~m}$ (length) $\times 14.2 \mathrm{~m}$ (width) x 50m (height). The layout plan of the Power house area is superimposed on the geological plan as shown in the Fig. 1 .

All the above structures are underground located inside a steep hill showing exposures of massive dolomite except the Surge shaft which is open to air at the top and is accommodated within dolomitic limestone with interbanding of schist, slate and metabasic rock. The underground Powerhouse is having installed capacity of 520 MW with four units of $130 \mathrm{MW}$ each.

The location of underground Powerhouse has been selected after undertaking series of geotechnical investigations at several alternative sites including an initial proposal of surface powerhouse. The various alternatives are sequentially discussed below:

\section{GEOTECHNICAL INVESTIGATIONS FOR SURFACE POWER HOUSE AT LARJI}

As per the project layout conceived during the feasibility stage, a surface Powerhouse has been proposed on a terrace towards the left bank of river Sainj near Larji village along with Penstocks and sub-surface Surge shafts and Pressure shafts. During this stage an alternative site for locating anunderground power house inside a rock spur located immediately downstream of the surface power house has also been studied. Detailed investigations were undertaken at the location of the surface power house in form of exploratory drilling, drifting and geophysical surveys. Detailed geological mapping undertaken in this area revealed that the bed rock consisting of dolomite with intermittent bands of quartzite and limestone has been exposed on the hill slope inside which important structures such as pressure Shaft and surge shaft were proposed. The bed rock has been intercepted by several weak bands of purple/black coloured shales. The geological cross section prepared for the location of surface power house is shown as Fig. 2.

Three numbers drill holes undertaken in this area indicated the overburden cover of about $25 \mathrm{~m}$ in this area consisting of boulders, cobbles and pebbles of slope wash material overlaid on river borne material. The bed rock encountered in these drill holes has been carbonaceous shales, purple shales and slates with quartzite. The details of the exploratory drill holes undertaken at this site are given in Table II. 


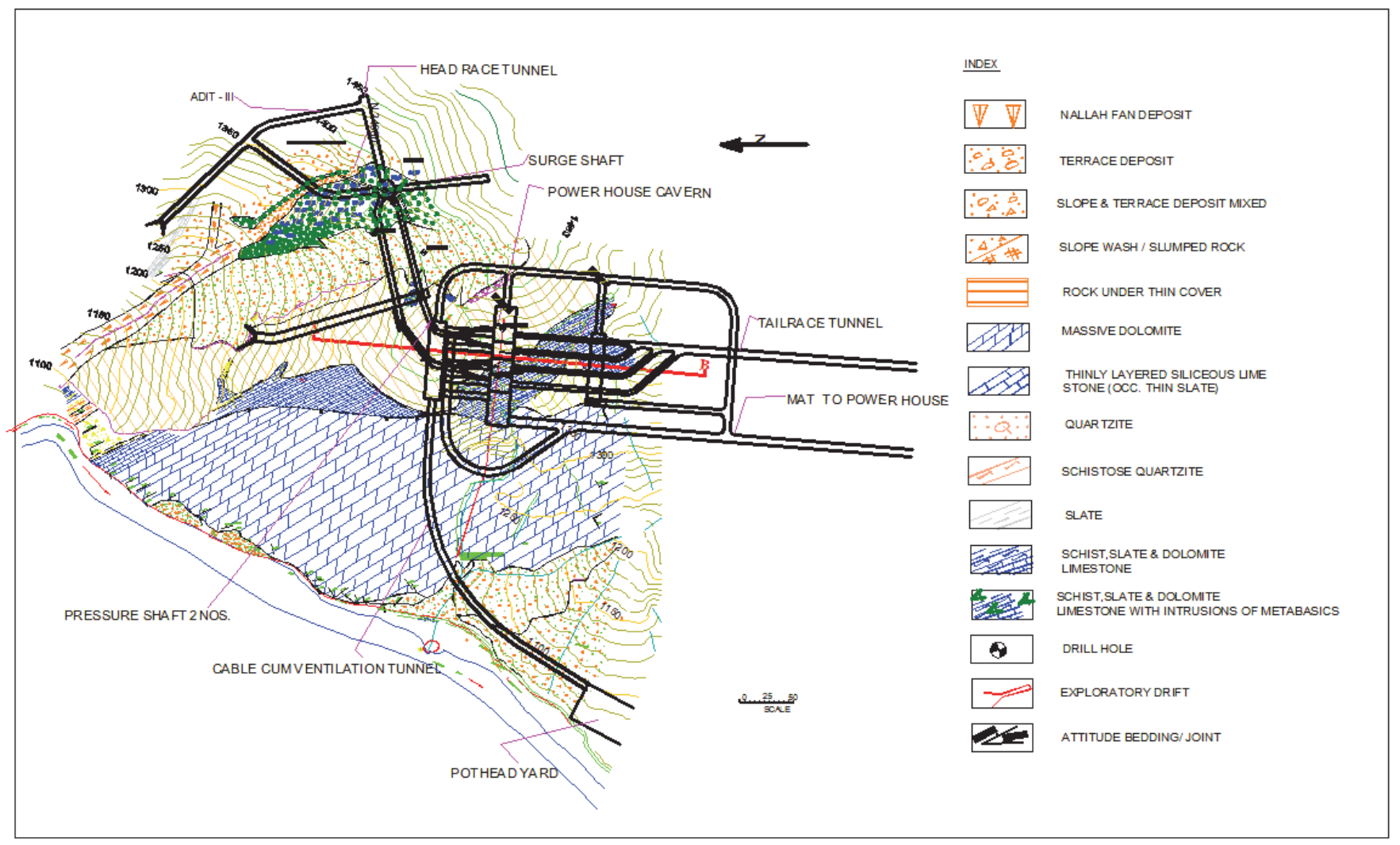

Fig. 1. Layout of power house complex superimposed on geological plan

Geophysical survey in form of Seismic refraction survey has also been undertaken on the old river terrace located towards the left bank of River Sainj at the site of proposed surface power house. Four nos. of seismic profiles have been undertaken in the area. Based on above survey a 3-D geological Model designated by seismic velocities has been developed as shown in Fig. 3.

Based on the seismic refraction survey the location of the proposed surface power house is covered with river borne material below a thin layer of scree material. The average thickness of overburden material has been interpreted of the order of $20 \mathrm{~m}$. The quality of the bedrock based on the recorded compression wave velocity is inferred to be average.

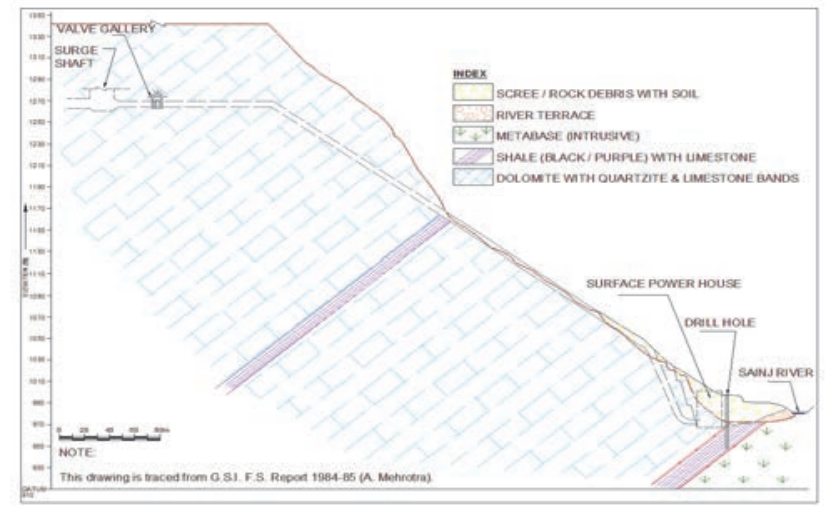

Fig. 2. Geological section at the location of proposed surface power house
Based on exploratory drilling data which has shown the presence of poor quality shales and slates in the foundation and geophysical survey results the site was not found suitable for locating a surface power house. Beside the geological and engineering considerations as presence of several multi storied buildings and habitation close to this alternative had also resulted in rejection of this site. Subsequently, investigation for alternative sites for underground powerhouse was undertaken.

\section{GEOTECHNICAL INVESTIGATIONS FOR UNDERGROUND POWER HOUSE}

\section{A. Alternative Site for underground powerhouse at Larji}

One of the sites identified for locating underground power house at Larji simultaneously with surface option was located immediately downstream of the terrace in a rock spur near Larji village. The site has been investigated with an exploratory drift of $88 \mathrm{~m}$ length with a $88 \mathrm{~m}$ upstream cross cut and $46.5 \mathrm{~m}$ long downstream cross cut.

In the main drift good quality metabasic rock of competent nature has been encountered. However in upstream and downstream crosscuts weak carbonaceous shale with thin bands of slates and quartzite has been encountered. As the competent band of metabasic rock encountered is not of sufficient width to house all the important structure of the powerhouse complex, this site was dropped. 
TABLE II. DESCRIPTION OF EXPLORATORY DRILL HOLES AT SURFACE POWERHOUSE LOCATION

\begin{tabular}{|l|l|l|l|}
\hline Drill Hole No & EL (M) & $\begin{array}{l}\text { Total Depth } \\
(\mathbf{m})\end{array}$ & $\begin{array}{l}\text { Depth of } \\
\text { Overburden }\end{array}$ \\
\hline PH & 999.9 & 50.00 & 25.00 \\
\hline
\end{tabular}

Overburden consisting of slope wash and debris material. Bed rock encountered includes carbonaceous shale with limestone.

\begin{tabular}{|l|l|l|l|}
\hline $\mathrm{DDH} / \mathrm{III} / 101$ & 1017.80 & 50.25 & 25.80 \\
\hline
\end{tabular}

Overburden consists of boulders, cobbles and pebbles in silty sand of slope wash and RBM. Bed rock consisting of closely foliated and jointed and fractured shale encountered. RQD varies from nil to $59.1 \%$. Bed rock permeability varies from 4.43 to 37.5 lugeon.

\begin{tabular}{|l|l|l|l|}
\hline $\mathrm{DDH} / \mathrm{III} / 102$ & 1056.30 & 60.15 & 25.01 \\
\hline
\end{tabular}

Overburden consists of boulders, cobbles and pebbles in silty sandy matrix of RBM. Bed rock consisting of greenish to blackish thinly foliated, fine grained, jointed and fractured slate with bands of jointed quartzite encountered. RQD varies from nil to $24.0 \%$. Bed rock permeability varies from 0.12 to 28.74 lugeon.

\section{B. Alternative Sites for underground powerhouse at Behali}

Another location near Bihali village about $2 \mathrm{~km}$ upstream of previous site was investigated for locating an underground power house. Exploratory drift of $350 \mathrm{~m}$ length has been excavated with $20 \mathrm{~m}$ cross cuts in upstream and downstream directions. The drift encountered slightly weathered to fresh, strong to very strong, jointed dolomite limestone up to

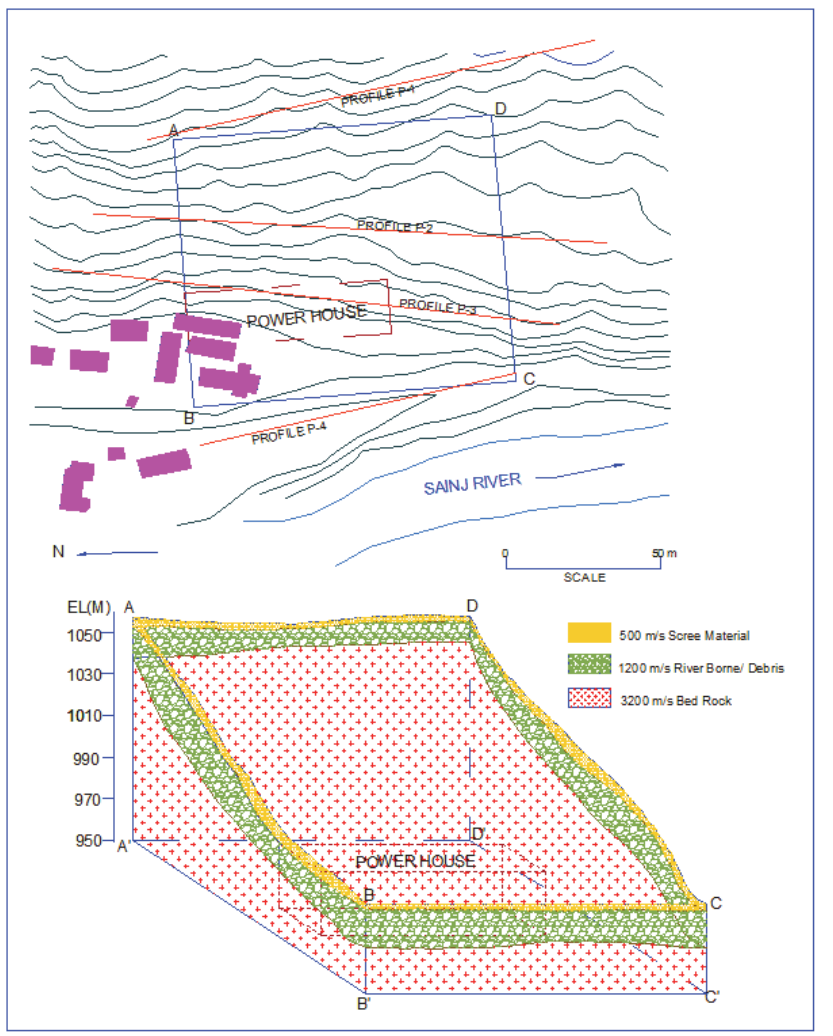

Fig. 3. Plan of left bank terrace at proposed surface power house showing seismic profiles and 3-D geological model developed based on seismic velocities

RD 156m. As per RMR classification, the rock has been categorized as Fair (Class-III) to Good (Class-II). However, beyond RD155m till end of the drift rock condition deterioted when weak carbonaceous slates along with thinly laminated slates were encountered. Between RD 300 up to end of the drift at $350 \mathrm{~m}$, Poor (Class-IV) to Very Poor (Class-V) rock conditions have been encountered (Table III). In this reach weak and thinly laminated bands of slates and carbonaceous slates were encountered which were highly jointed and susceptible to collapse even in dry seepage conditions. In the upstream and downstream crosscuts also which were excavated at RD $350 \mathrm{~m}$, these weak bands of carbonaceous slates continued. The overall 25\% Class-II (Good), 56\% Class-III (Fair) and 19\% Class-IV (Poor)/ Class-V (Very Poor) RMR Rock Classes were encountered in this drift (Fig. 4).

As shown in Table III, the underground media was predominantly comprised of poor to very poor quality slates and carbonaceous slates. With its low strength and prone to collapse these rocks were not suitable for excavating large size caverns. A competent band of dolomite limestone with very limited extent varying between 120 to $100 \mathrm{~m}$ width could be found at this proposed site which was not sufficient to house major components of power house complex. Considering the above geological conditions this site was rejected.

Series of geotechnical investigations at the two previously explored sites, suitable rock units for housing all the major components of power house complex could not be accomplished due to highly variable lithology characterized by presence of weak bands of slates/carbonaceous slates, shales and phyllites intermittently between competent bands of dolomitic limestone. In such geological condition it seemed difficult to safely accommodate large caverns such as machine hall, transformer hall and downstream surge chambers search unless and until consistency of some competent litho unit is essentially assured for considerable extent.

Subsequently, detailed mapping on 1: 1000 scale was undertaken and meticulous search for some competent rock band was made. The road section provided a comprehensive insight about variation in dispositions of different litho units of Larji group in this area. One of the steeply sloping ridge about $500 \mathrm{~m}$ upstream of previously investigated area exhibited presence of a hard, massive and competent band of dolomite lime stone on the road cutting. Prima facie the dolomite band which was extending for about $300 \mathrm{~m}$ along dip direction was found suitable for hosting the powerhouse complex.

By detailed geological mapping its extension along the strike direction was also established. In general the dolomitic limestone beds were having an average orientation of 0550/650 whereas other rock units towards the upstream side such as schistose quartzite, siliceous quartzite, slate, schists and phyllites interbanded with limestone were showing steeper dips of 700 to 750 . As shown in the geological plan enclosed as Fig. 1 above, the layout was modified and powerhouse complex was placed within the massive dolomite band. 
TABLE III. DESCRIPTION OF ROCKMASS BASED ON 3-D GEOLOGICAL LOG OF T2HE EXPLORATORY DRIFT

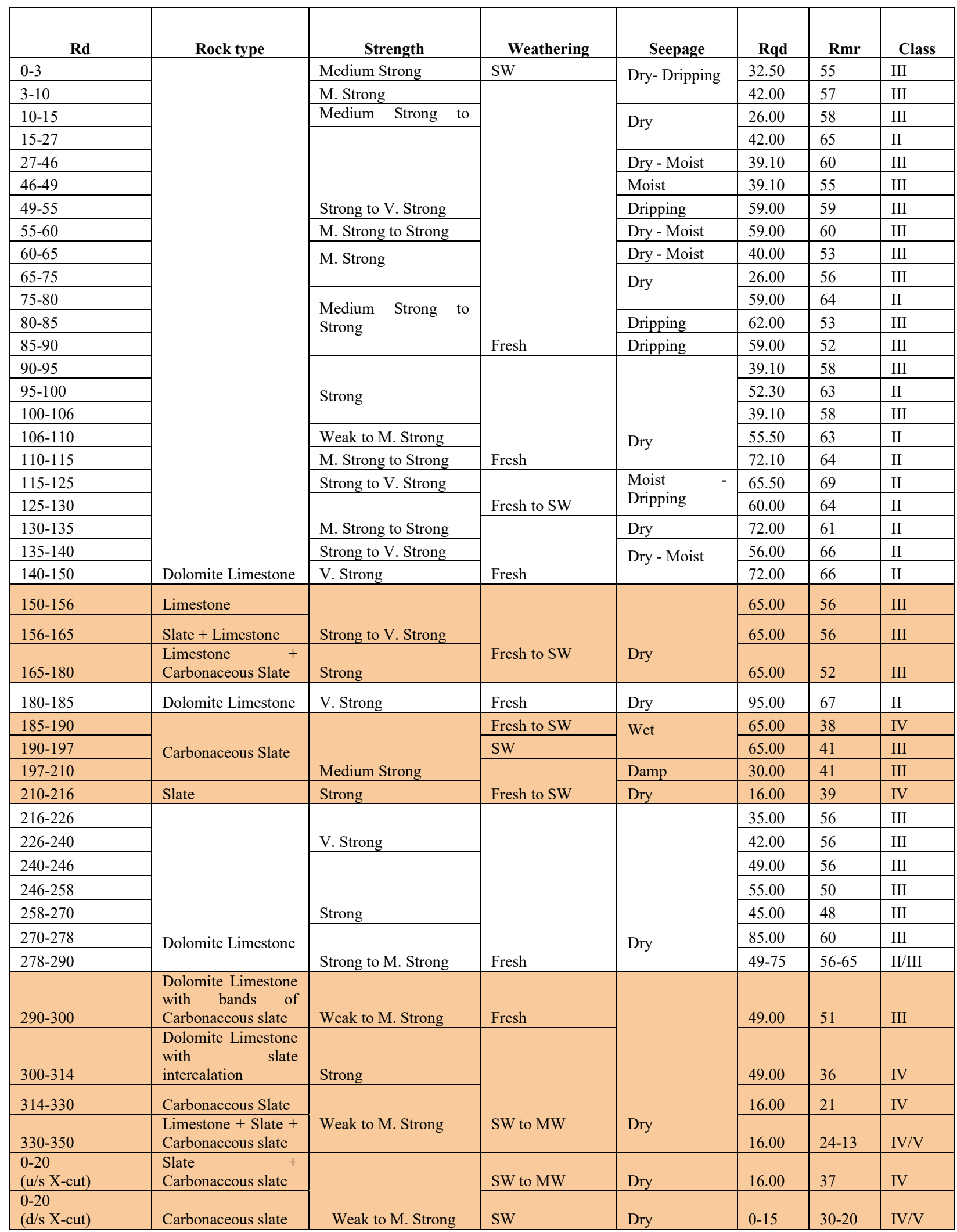


However, before firming up the layout it was essential to establish the continuity of the dolomite band inside the ridge in order to affirm its extension for all large caverns of the powerhouse complex. With this purpose, the site was further investigated by an exploratory drift of $250 \mathrm{~m}$ extent with portal invert level at EL $1075 \mathrm{~m}$. The drift was initially aligned in 1020 direction however after RD 103m; the alignment of this drift is made 970 which is almost parallel to longer axis of the machine hall. One crosscut of $80 \mathrm{~m}$ length in upstream direction and another of $20 \mathrm{~m}$ length in downstream direction were also excavated. This drift throughout its length has encountered massive dolomite intercepted by few shear seams and fracture zones of thickness ranging from 10 to $20 \mathrm{~cm}$. one or two bands of fractured rock mass having thickness less than $1 \mathrm{~m}$ were also intercepted. The drifts have been geologically logged to map the rock mass details.

Overall, in accordance to the RMR system of classification about 64\% Class-II (Good), 32\% Class-III (Fair) and 04\% Class-IV (Poor) category rock mass has been encountered (Fig. 5).

The powerhouse area was further explored by means of two nos drill holes of $120 \mathrm{~m}$ depth drilled inside drift at RD's180 and $240 \mathrm{~m}$ respectively. Better rock conditions wereencountered in the formal drill hole in which average RQD has been $49.75 \%$ in comparison to $30.33 \%$ in the later. The dolomite rock is massive however it is traversed by four major joint sets. The ranges of attitudes of various joint sets along with their average orientation and angle with longer axis of power house are shown in Table IV.

TABle IV. ATtitudes of Prominent JoINT Sets In Powerhouse AREA

\begin{tabular}{|l|l|l|l|}
\hline $\begin{array}{l}\text { Joint } \\
\text { Set No }\end{array}$ & Range of Attitude & $\begin{array}{l}\text { Average } \\
\text { Orientation }\end{array}$ & $\begin{array}{l}\text { Angle with } \\
\text { longer Axis of } \\
\text { Powerhouse }\end{array}$ \\
\hline S-1 & $\begin{array}{l}0480 / 830 \\
0720 / 660\end{array}$ & $0550 / 700$ & 350 \\
\hline S-2 & $\begin{array}{l}3020 / 870 \\
3330 / 320\end{array}$ & $3170 / 590$ & 470 \\
\hline S-3 & $\begin{array}{l}1230 / 450- \\
1590 / 800\end{array}$ & $1410 / 650$ & 510 \\
\hline S-4 & $\begin{array}{l}2070 / 490- \\
2680 / 680\end{array}$ & $2370 / 580$ & 390 \\
\hline
\end{tabular}

The alignment of the power house cavern was fixed after detailed analysis. The longer axis of the cavern is aligned East-West. The S-1 joint which represents the bedding plane is not prominent joint sets in the dolomite occurring in this area. Therefore, S-1 does not have much impact on deciding the alignment of the powerhouse cavern. Since S-3 which is the most prominent joint set at this location is sufficiently oblique so are S-2 and S-4 joint sets. Thus the above alignment is suitable w.r.t. orientation of the major joint sets.

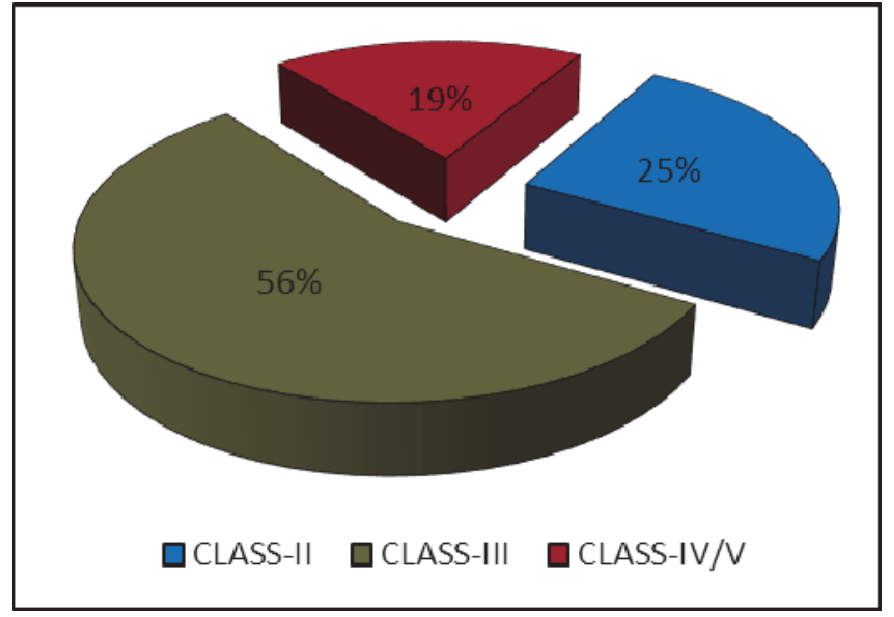

Fig. 4. RMR rock classes in $350 \mathrm{~m}$ long exploratory drift in percentage

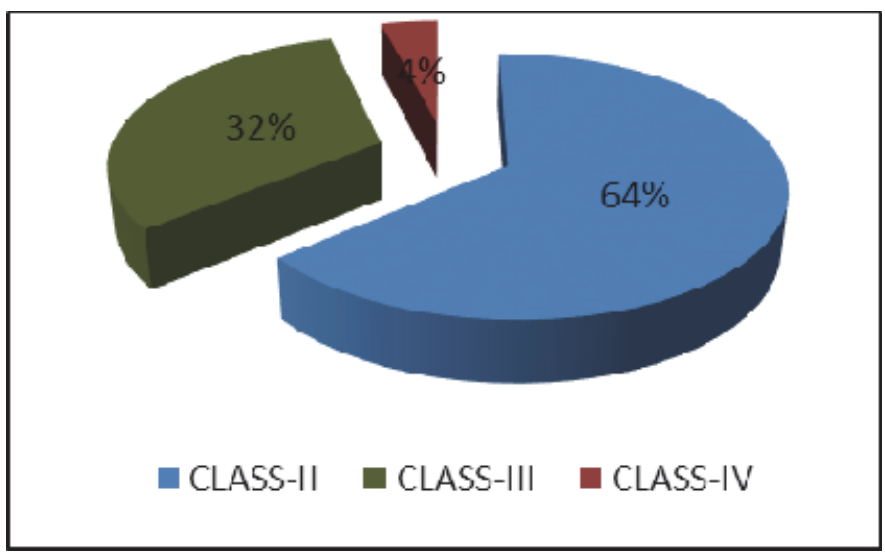

Fig. 5. RMR rock classes in $250 \mathrm{~m}$ long exploratory drift in percentage

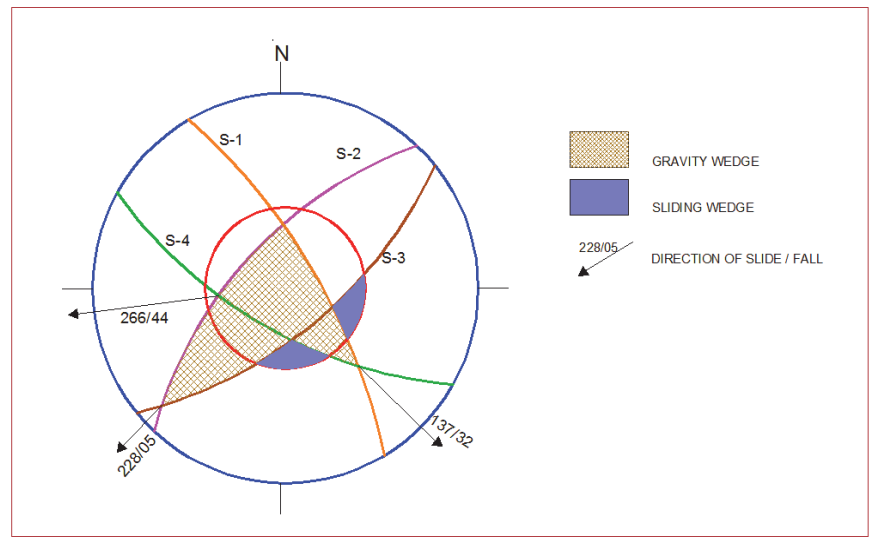

Fig.6.Stability analysis for major joint sets using stereo plot for underground powerhouse cavern

The Hydro-fracture tests conducted for insitu stress measurements in the two nos. drill holes located inside powerhouse drift at RD's 180 and $240 \mathrm{~m}$ respectively revealed that major principal horizontal stress $(\sigma \mathrm{H})$ is oriented along N 500 to N600 direction which is oblique to the alignment of powerhouse cavern.

Considering the above major joint sets, stability analysis for identifying various wedges formed due to intersection of 
joint sets using stereo plot has been undertaken as shown in Fig. 6. The angle of internal friction (Ø) considered is 350. The sliding wedges are formed in the wall of the cavern by intersection of S-1 and S-4 joint sets while gravity wedges in roof are formed by intersection of S-1 and S-3and S-2 joint sets S-2, S-4 and S-1 joint sets. The support systems designed for the powerhouse cavern take into account the above wedges.

The laboratory rock mechanics tests have been conducted on the core samples collected from the two nos. drill holes inside powerhouse drift at RD's $180 \mathrm{~m}$ and $240 \mathrm{~m}$ respectively to determine various engineering properties of the intact rock.

TABLE V. ENGINEERING PROPERTIES OF INTACT ROCK SAMPLES FROM DRILL HOLES INSIDE THE POWERHOUSE DRIFT

\begin{tabular}{|l|l|l|}
\hline \multirow{2}{*}{ Engineering Properties } & \multicolumn{2}{|l|}{ Average Values } \\
\cline { 2 - 3 } & RD 180m & RD 240m \\
\hline UCS (Dry) in MPa & 172.8 & 58.22 \\
\hline UCS (Saturated) in MPa & 144.0 & 35.10 \\
\hline Tensile Strength in MPa & 20.1 & 8.80 \\
\hline Cohesion (C) in MPa & 21 & 7 \\
\hline Friction Angle in Degree & 40 & 33 \\
\hline Modulus of Elasticity in MPa & 22.6 & 16.27 \\
\hline Poisson's Ratio & 0.09 & 0.08 \\
\hline
\end{tabular}

As discussed earlier, the rock quality obtained in the later drill hole was inferior in comparison to former the same is reflected in the results shown in Table V.

The Goodman Jack tests conducted in the two drill holes at several depths in order to determine the rock moduli. The tests were conducted perpendicular and parallel to the longer axis of powerhouse cavern in order to incorporate the anisotropy in the test results. The tests have been conducted in three cycles wherein maximum pressure has been $2 \mathrm{MPa}, 4$ $\mathrm{MPa}$ and $7 \mathrm{MPa}$ respectively. The mean values of the rock moduli estimated at peak pressure for different depths in each drill hole is summarized in Table VI.

TABLE VI. MEAN ROCK MODULI VALUES FOR TWO DRILL HOLES

\begin{tabular}{|l|l|l|}
\hline \multirow{2}{*}{} & Mean Values \\
\cline { 2 - 3 } & RD 180m & RD 240m \\
\hline Modulus of Deformation ( Ed) & 11.591 & 10.444 \\
\hline Modulus of Elasticity (Ee) & 17.572 & 15.731 \\
\hline Modulus Ratio (Ee/Ed) & 1.513 & 1.458 \\
\hline
\end{tabular}

The moduli values show that the rock is competent and there is no appreciable difference in the values obtained from two drill holes. At the same time there has been no directional variability in respect of direction of longer axis of powerhouse cavern. Any depth wise variation in modulus values has not been observed however interrelationship with RQD could be established wherein higher deformation modulus was obtained in good quality rock mass designated by higher RQD values.

Based on the surface exposures and subsurface geological investigation undertaken in the powerhouse area a geological section is developed in order to interpret the disposition of various litho units is shown in Fig. 7,. Lateral cover of about $350 \mathrm{~m}$ and superincumbent cover of about $300 \mathrm{~m}$ is available for the powerhouse cavern.

\section{ROLE OF GEOTECHNICAL INVESTIGATIONS}

Systematic and well planned geological and geotechnical investigations undertaken during Detailed Project Report (DPR) stage play a crucial role in firming up the layout of the hydropower projects. In the Himalayan region, the geology is highly varying in nature due to which in-depth understanding of geology of the project area is very important. Due considerations given to geological investigations while designing of various structures in DPR

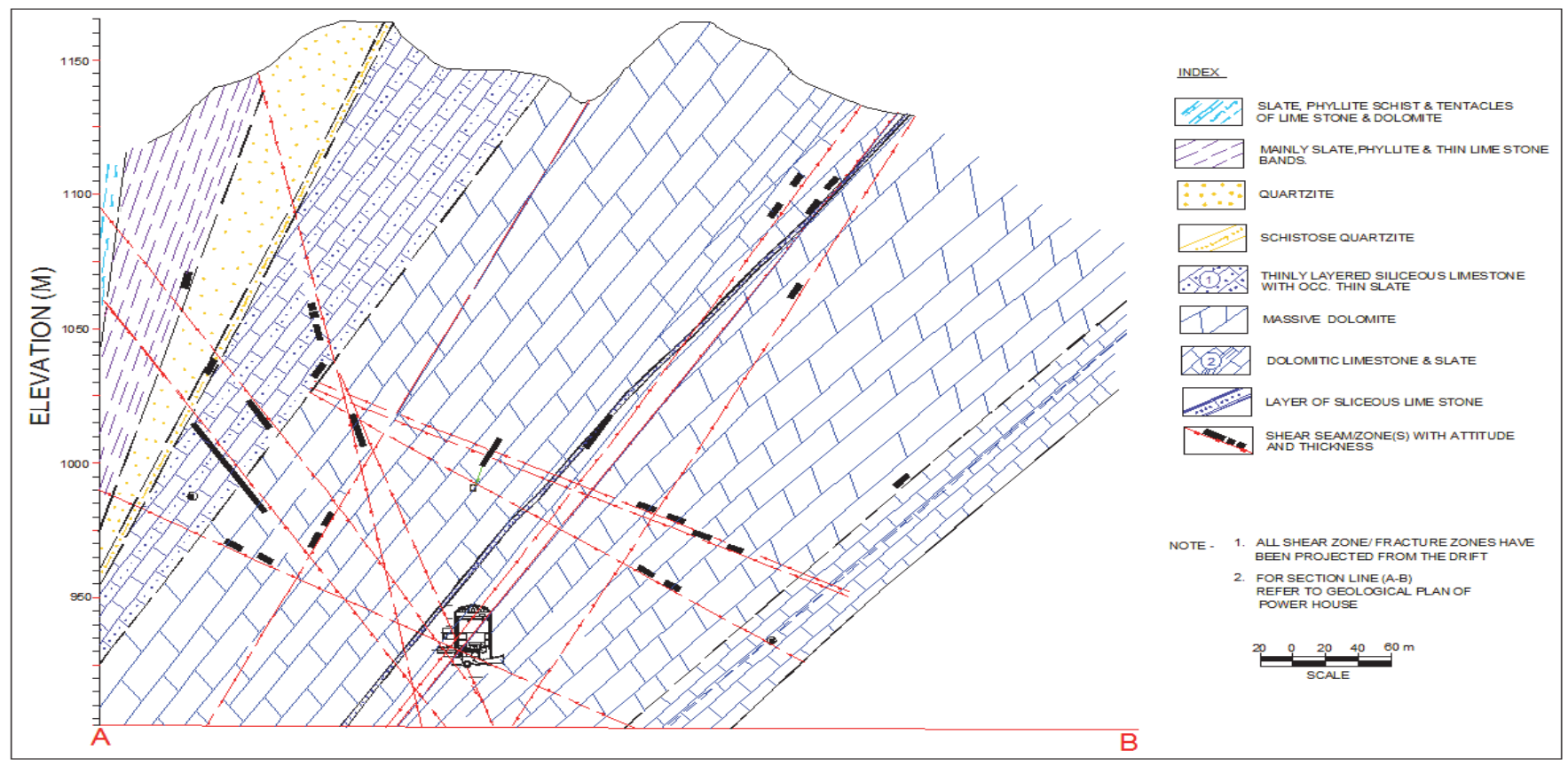

Fig.7. Geological Cross section across powerhouse cavern located within band of massive dolomite 
stage help in minimizing the geological uncertainties during execution. The efforts put by the developer for locating a competent band of massive dolomitic limestone of appreciable thickness within a highly varying lithology of Larji Group consisting of alternating sequence of slates, carbonaceous slates, phyllites and siliceous quartzite has been very challenging. Moreover, decision taken for locating the underground powerhouse complex within this competent band of dolomite has benefitted the developer resulting in timely construction of the structures without any cost escalation.

\section{CONCLUSIONS}

Development of hydropower is very important to achieve the energy security of our country. A large percentage of untapped hydro-potential is located within the Himalayan region which is tectonically active and structurally deformed. For successful execution of hydro projects which involve construction of several surface and subsurface structures the Geological and geotechnical investigations should be given due importance while deciding the layout of the project. Well considered decisions taken during DPR stage itself reduces the risks of geological uncertainties during construction.

\section{ACKNOWLEDGMENT}

The authors are indebted to the management of NHPC Ltd. forgranting permission to publish the above work. The authors are also grateful to various agencies which were involved with various testing at the project site.

\section{REFERENCES}

[1] N. Barton, ZT Bieniawski, (2008). RMR and Q-Setting Records, Tunnels \& Tunnelling International, (Feburary 2008), pp 26-29.

[2] N.Barton, R.Lien and J.Lunde (1974). Engineering Classification of Rock Masses for the Design of Tunnel Support. Rock Mechanics (Vol6, pp 189-236). New York, Springer.

[3] Bhawani Singh \& R. K. Goel (1999). Rock Mass Classification- A Practical Approach to Civil Engineering. Elsevier Science Ltd., B. K.

[4] Bieniawski Z.T., (1976). Rock Mass Classifications in Rock Engineering. In Proceedings of the Symposium on Exploration for Rock Engineering (pp. 97-106).

[5] CSMRS, “ Report on determination of in-situ stress by hydrofracture method and deformability parameters by Goodman jack test at proposed powerhouse site of Parbati HE Project, Himachal Pradesh", February 2004.

[6] Hoek, E., \& Brown E. T., (1980). Underground Excavation in Rock: Institute of Mining \& Metallurgy, London, Maney Publishing.

[7] NHPC Ltd., " Detailed Project Report of Parbati HE Project, stage-III, Himachal pradesh". August 2003.

[8] Srikantia, S.V. (1988). Himalayan thrusts and structural belts. Journal Geological Society of India, 31, 210-229.

[9] Srikantia, S.V. and Bharagava, O.N. (1998). Geology of Himachal Pradesh, Geological Society of India Publication, pp 406. 